\title{
FIRST EPIDEMIOLOGICAL DESCRIPTION OF TEGUMENTAR AND VISCERAL LEISHMANIASIS IN PATROCÍNIO MUNICIPALITY, MINAS GERAIS (2000-2017)
}

\author{
PRIMEIRA DESCRIÇÃO EPIDEMIOLÓGICA DE LEISHMANIOSE TEGUMENTAR \\ E VISCERAL NO MUNICÍPIO DE PATROCÍNIO, MINAS GERAIS (2000-2017)
}

\author{
Débora Cristina de Oliveira Silva Nunes ${ }^{1}$; Layla Gabrielle Silva Paulista ${ }^{2}$; \\ Samarah Borges Nunes Ribeiro ${ }^{2}$; Ana Luiza Borges de Paula Nunes ${ }^{3}$ \\ 1. Professor, Dra. Genética e Bioquímica, IFTM campus Patrocínio, MG, Brasil. nunesdco@yahoo.com.br; 2. Estudante, \\ IFTM campus Patrocínio, MG, Brasil. bolsista PIBIC; 3. Professor, Ma. Ecologia e Conservação de Recursos Naturais IFTM campus \\ Patrocínio, MG, Brasil
}

\begin{abstract}
Leishmaniasis is a disease that can affect visceral organs (visceral leishmaniasis; VL) or mucous membranes and skin, causing lesions of different forms and levels of severities (tegumentary leishmaniasis; TL). Like several others, leishmaniasis is a neglected disease, as the pharmaceutical industry seems to show little to no interest in developing new drugs targeting the disease. This study aims to trace the epidemiological profile of leishmaniasis in the Municipality of Patrocínio, State of Minas Gerais, over a period of time. Secondary data of reported cases from 2000 to 2017 were analyzed as provided by the Patrocinio Health Department. As no literature was found on the status of such a disease in Patrocinio, it is important to trace the epidemiological profile of leishmaniasis in the area. The findings pointed out that the disease affected predominantly male in the economically active population, mainly from the urban area, and that it had no relationship with professional activity. Twenty-two cases of leishmaniasis (15 of TL and 7 of VL) were reported, all of which were treated and cured. Five cases of TL and 1 case of VL were autochthonous, and confirmed cases of canine infection took place in 2011, 2016 and 2017.
\end{abstract}

KEYWORDS: Alto Paranaíba. Autochthonous. Human leishmaniasis. Triângulo Mineiro.

\section{INTRODUCTION}

Leishmaniasis is a parasitic disease caused by protozoa of the Leishmania genus, which are transmitted from one host to another by phlebotomine sandflies (NAGLE et al., 2014). It may affect both visceral organs and skin surfaces (HANDLER et al., 2015) and lead to four major clinical syndromes: cutaneous leishmaniasis (CL), mucocutaneous leishmaniasis (MCL), visceral leishmaniasis or kala-azar (VL) and post-kala-azar dermal leishmaniasis (PKDL) (ANVERSA et al., 2018).

Leishmaniasis is treated as a public health problem due to its high incidence and the disorders it can cause to the affected individuals. TL is characterized by ulcers on the face and/or extremities and nasal/oral/pharyngeal mucous (HANDLER et al, 2015), which can cause deformities such as disfiguring and permanent scars with partial or total mutilation of the nasopharyngeal mucosa, with further social, economic and psychological implications (ANVERSA et al., 2018, SUNYOTO; BOELAERT; MEHEUS, 2019). The mortality rate for VL, a more severe form, is $10 \%$, making it the second most deadly tropical parasitic infection in the world after malaria (HANDLER et al., 2015).

Updated regional information on the disease is important for epidemiological surveillance. However, the actual number of leishmaniasis cases is unknown due to underreporting, lack of epidemiological surveillance system or adequate diagnostic methods. Most data on incidence rates are based on estimates (PACE, 2014). Around 1.5 to 2 million new cases of leishmaniasis are estimated to occur annually worldwide: 500,000 are VL; 1 to 1.5 million cases are related to cutaneous or mucocutaneous leishmaniasis. Both forms commonly occur in Brazil (ANVERSA et al., 2018; WHO, 2020).

Silva (2017) reported that the highest incidence rates of VL in the State of Minas Gerais, Brazil, from 2002 to 2013 were concentrated in the mesoregions in the North (Noroeste de Minas, Norte de Minas, and Jequitinhonha), in the East (Vale do Rio Doce) and in the center of the state (Central Mineira and Metropolitana de Belo Horizonte). The other mesoregions (Campo das Verentes, Oeste de Minas, Sul/Sudoeste de Minas, Triângulo 
First epidemiological description...

Mineiro/Alto Paranaiba, Vale do Mucuri, and Zona da Mata) showed a small number of cases of VL.

The literature provides few information about leishmaniasis in the mesoregion known as Triângulo Mineiro e Alto Paranaiba, in the West of the state. Fourteen human cases were reported in the region from 1981 to 1986 (MACHADO et al., 1988; NISHIOKA et al., 1988), and an outbreak of CL occurred in the Municipalities of Uberlândia and Indianópolis in 1987 (MACHADO et al., 1992). Due to this microepidemia, the infection of dogs in rural and urban areas in the municipalities of Uberlândia and Coromandel was investigated and an active canine infection was observed in the region. Thus, it was considered that dogs, as important reservoirs of the disease, could form new endemic outbreaks in urban areas (MAYWALD et al., 1993; 1996). (MAYWALD et al., 1993; 1996).

Recently, Araújo and Nunes (2017) described the characteristics of cases of leishmaniasis treated in Uberlândia (Minas Gerais), between 2000 and 2013. While they found no confirmed case of autochthonous leishmaniasis, they pointed to problems related to underreporting and lack of complete information in the medical records. A study evaluated the positivity rate for leishmaniasis in asymptomatic animals treated at the Veterinary Hospital of Universidade Federal de Uberlândia, from August to November 2017, and showed an infection rate of $26 \%$ (MENDONÇA, 2018). Some studies have identified the presence of disease vectors in the Araguari river basin (LEMOS; LIMA, 2005; PAULA et al., 2013), in the urban area (PAULA et al., 2008) and in Parque do Sabiá, a large park and zoo area in the East of the city (RODRIGUES et al., 2011).

The topic is relevant given the severity of leishmaniasis as a public health problem and the lack of studies addressing its epidemiology in the Municipality of Patrocínio. This study aimed to provide the first epidemiological description of the disease in Patrocínio. Such a description is likely to provide useful information to both the population and the sanitary authorities.

\section{MATERIAL AND METHODS}

\section{Study area}

Patrocínio is located in the State of Minas Gerais, in the mesoregion known as Triângulo Mineiro and Alto Paranaíba, with a latitude 18 56'38" South and longitude 46 59'34" West (IBGE, 2019). It has an area of $2,874.344 \mathrm{~km}^{2}$ and an estimated population of 90,041 inhabitants (IBGE, 2019). The predominant climate is tropical,
NUNES, D. C. O. S. et al.

the average annual temperature is $20.7^{\circ} \mathrm{C}$, and the characteristic vegetation is tropical savanna, known as "cerrado" (SILVA; MALVINO, 2005; PREFEITURA DE PATROCÍNIO, 2019).

\section{Study design}

This is a descriptive, observational, longitudinal and retrospective survey (HOCHMAN et al., 2005) on the epidemiology of leishmaniasis in the Municipality of Patrocínio. Two types of data were collected: 1) on the victims of leishmaniasis, and 2) on the infection of dogs. Victims were analyzed based on secondary data obtained from the Brazilian Information System for Notifiable Diseases (SINAN). The population consisted of patients with clinical, epidemiological and/or laboratory diagnosis of cutaneous or mucosal leishmaniasis (ICD B 55.1) and visceral leishmaniasis (ICD B55.0) from January 2000 through December 2017. Secondary data on both victims and dogs were provided by the Patrocinio Health Department. The researchers obtained coded secondary data and carried out data collection and analysis at Instituto Federal do Triângulo Mineiro. The secondary data were first decoded based on the compulsory notifications of leishmaniasis and then analyzed in tables.

\section{RESULTS AND DISCUSSION}

The Patrocínio Health Department provided two data groups: cases notified according to the municipality of residence, and cases notified in Patrocínio. In the present study, the data refer to the residents of Patrocínio whose disease was treated and notified in the municipality.

All 15 cases of TL in residents of Patrocínio were notified in the municipality. Meanwhile, 7 out of the 12 cases of VL in residents of Patrocínio were notified in the municipalities; 3 of these 12 cases were confirmed ( 2 imported, and 1 autochthonous); only the autochthonous case was notified in the city. By analyzing secondary data, it is not possible to know the reason for non notification in the municipality itself. One possibility is that such patients were seen in other municipalities and consequently notified in other locations, or there was no notification for those unconfirmed suspected cases. Notifiable diseases are those that require "mandatory notification of suspected or confirmed cases of disease, injury or public health event to the health authorities by physicians, health professionals or those responsible for health facilities" (MINISTERIO DA SAUDE, Administrative Rule No. 204, as of 17 February 2016), as this allows for 
health surveillance and appropriate course of actions. In Brazil, notification is mandatory for confirmed cases of cutaneous, mucous and visceral leishmaniasis and suspected cases of visceral leishmaniasis (BRASIL, 2014; 2017).

A total of 22 cases of leishmaniasis were found in the municipality of Patrocínio, 7 of visceral and 15 tegumentar (14 CL and $1 \mathrm{MCL}$ ) form. According to Silva (2017), most cases of VL in Minas Gerais occur in Belo Horizonte, Montes
Claros, and Paracatu. Other municipalities such as Aracuai, Betim, Contagem, Curvelo, Governador Valadares, Janaúba, Joao Pinheiro, Sete Lagoas, Ribeirão das Neves, Santa Luzia, and Unaí also have a significant number of cases of VL notified, including for residents. Cases notified in Patrocínio decreased gradually over the years, except for year 2015 which had the largest record of cases in the period (Table 1).

Table 1. Distribution of human tegumentary and visceral leishmaniasis cases and records of canine visceral leishmaniasis, in Patrocínio, 2000-2017.

\begin{tabular}{|c|c|c|c|c|c|}
\hline \multirow{2}{*}{ Year } & \multicolumn{2}{|c|}{ Human leishmaniasis } & \multicolumn{3}{|c|}{ Canine visceral leishmaniasis } \\
\hline & TL & VL & Notified & Confirmed & Undetermined \\
\hline 2010 & 3 & 0 & -- & -- & -- \\
\hline 2011 & 2 & 0 & 1 & 1 & 0 \\
\hline 2012 & 2 & 0 & 6 & 0 & 1 \\
\hline 2013 & 1 & 0 & 4 & 0 & 0 \\
\hline 2014 & 1 & 0 & 0 & 0 & 0 \\
\hline 2015 & 5 & 0 & 0 & 0 & 0 \\
\hline 2016 & 1 & 2 & 2 & 1 & 0 \\
\hline 2017 & 0 & 5 & 9 & 3 & 0 \\
\hline Total & 15 & 7 & 22 & 5 & 1 \\
\hline
\end{tabular}

The analysis also targeted canine visceral leishmaniasis. Three of the 12 cases of VL reported in residents of Patrocínio were confirmed (2 were imported and not notified in Patrocínio, and only 1 was autochthonous and notified in Patrocínio). The autochthonous case occurred in 2017, the year when canine visceral leishmaniasis was confirmed, and the other 2 cases, occurred in 2010 and 2014. No information was available on dog infection in 2010 and it had not been confirmed in 2014 (data not shown).

Vertebrate hosts of the various species of Leishmania include a wide variety of mammals, such as rodents, canines, marsupials, edentates, carnivores, primates and humans (ANVERSA et al., 2018). Regarding the cutaneous form of human leishmaniasis, domestic animals do not seem to play a role as reservoirs of Leishmania species, being considered accidental hosts of the disease. In contrast, dogs are the main reservoir and source of infection by the visceral form of human leishmaniasis in urban environments (BRASIL, 2016). From an epidemiological point of view, canine visceral leishmaniasis is very dangerous because dogs maintain the infectious state for a long time, often have high parasitic loads on their skin, and are usually asymptomatic, thus playing an active role in the transmission of the disease (BORGES, 2008).
As shown in Table 2, the patients affected by leishmaniasis (TL and VL) had the following profile: most were male and in adulthood and economically active, followed by the elderly and children. This same profile was verified in other studies evaluating TL (VIANA et al., 2012; SILVA et al., 2014) and VL (SOUSA et al., 2008) in Montes Claros and TL and VL in Uberlandia (ARAÚJO; NUNES, 2017), both in the state of Minas Gerais.

The secondary data did not provide information on the patients' professional activities, but informed absence of relationship between the disease and victims' professional for confirmed cases of both TL or VL. Besides, most of the victims lived in the urban area, which is consistent with the literature (VIANA et al., 2012; SILVA et al., 2014; SILVA, 2017). The neighborhoods for TL were: Boa Esperanca, Centro, Nossa Senhora de Fatima, Sao Cristovao, Sao Lucas, Sao Vicente, and Vila Constantino. As for VL, only the neighborhood of Serra Negra was mentioned.

The typical leishmaniotic lesion was present in all tegumentary cases. Most cases were CL, and only one was MCL, i.e., the one which can be disfiguring and life-threatening (HANDLER et al., 2015). Other studies on TL in Minas Gerais have also found that the cutaneous form was more 
frequent than the mucocutaneous (VIANA et al., 2012; SILVA et al., 2014).

Table 2. Victims profile of tegumentary and visceral leishmaniasis in Patrocínio (MG), 2000-2017.

\begin{tabular}{llcccc}
\hline \multirow{2}{*}{ Feature } & & \multicolumn{2}{c}{ TL } & \multicolumn{2}{c}{ VL } \\
\cline { 3 - 5 } Sex & Female & $\mathbf{N}$ & $\mathbf{\%}$ & $\mathbf{N}$ & $\mathbf{\%}$ \\
& Male & 0 & 0.00 & 3 & 42.86 \\
& Not informed & 15 & 100.00 & 4 & 57.14 \\
\multirow{3}{*}{ Age group } & $0-19$ & 0 & 0.00 & 0 & 0.00 \\
& $20-59$ & 1 & 6.67 & 0 & 0.00 \\
& $\geq 60$ & 11 & 73.33 & 6 & 85.71 \\
\multirow{2}{*}{ Area } & Rural & 3 & 20.00 & 1 & 14.29 \\
& Urban & 6 & 40.00 & 1 & 14.29 \\
Total & Not informed & 9 & 60.00 & 1 & 14.29 \\
& & 0 & 0.00 & 5 & 71.43 \\
\hline
\end{tabular}

All patients showed fever, weakness, infectious condition in the visceral form (Table 3). Other clinical manifestations included pallor, jaundice, weight loss, enlarged spleen and, less commonly, edema, cough and/or diarrhea and pancytopenia. Parasite proliferation in the macrophages of spleen, liver and bone marrow of VL patients results in prolonged fever, pancytopenia, progressive anemia, weight loss, progressive hepatosplenomegaly, and immunosuppression (MCGWIRE; SATOSKAR, 2014; PACE, 2014; 141 SUNDAR; CHAKRAVARTY, 2015). If these are left untreated, the disease may result in severe weight loss, propensity for secondary infections, and death (MCGWIRE; SATOSKAR, 2014; PACE, 2014).

No record of co-infection with either TL or VL was found, which is also a favorable finding. HIV-infected patients are known to have a higher risk of severe and widespread TL, recurrence and treatment failure. They may also develop visceral leishmaniasis in the presence of Leishmania species that are generally only dermotropic. Moreover, leishmaniasis interferes in the monocyte and macrophage's function, which facilitates HIV progression (MARTÍNEZ et al., 2018).

Table 3. Clinical manifestations presented by victims of visceral leishmaniasis in Patrocínio (MG), 2000-2017.

\begin{tabular}{lccccc}
\hline \multirow{2}{*}{ Signs and symptoms } & \multicolumn{2}{c}{ Yes } & \multicolumn{2}{c}{ No } & \multirow{2}{*}{ Total } \\
\cline { 2 - 5 } & $\mathbf{N}$ & $\mathbf{\%}$ & $\mathbf{N}$ & $\mathbf{\%}$ & \\
\hline Fever & 7 & 100.00 & 0 & 0.00 & 7 \\
Weakness & 7 & 100.00 & 0 & 0.00 & 7 \\
Edema & 1 & 14.29 & 6 & 85.71 & 7 \\
Weight loss & 2 & 28.57 & 5 & 71.43 & 7 \\
Cough and/or diarrhea & 1 & 14.29 & 6 & 85.71 & 7 \\
Pallor & 4 & 57.14 & 3 & 42.86 & 7 \\
Increased spleen & 2 & 28.57 & 5 & 71.43 & 7 \\
Infection & 7 & 100.00 & 0 & 0.00 & 7 \\
Hemorrhagic phenomenon & 0 & 0.00 & 7 & 100.00 & 7 \\
Increased liver & 2 & 28.57 & 5 & 71.43 & 7 \\
Jaundice & 3 & 42.86 & 4 & 57.14 & 7 \\
Others & 1 & 14.29 & 6 & 85.71 & 7 \\
\hline
\end{tabular}

Laboratory diagnosis contributes to confirming cases and complementing the epidemiological and clinical investigation. The criterion for confirmed diagnosis was mostly laboratorial (93\%) in Patrocínio (see Table 4), which is consistent with other studies (SILVA, 2017; ARAUJO; NUNES, 2017).
The most common tests for diagnosis of TL were the Montenegro skin test (MST) and histopathology. The laboratory diagnosis of TL can be carried out by: (1) direct identification of amastigotes on lesion smear, tissue fragment imprinting or by parasite cultures in artificial media (parasitological); (2) histopathology, an important 
First epidemiological description...

method for ruling out diseases that are clinically similar to TL; (3) by immunological methods, such as indirect immunofluorescence, whereby antiLeishmania antibodies are detected by serological tests, and (4) the Montenegro skin test (leishmanin intradermal skin test) based on delayed cell hypersensitivity response (ELMAHALLAWY et al., 2014; BRASIL , 2017). According to Viana et al. (2012), Montenegro's reaction has more sensitivity than indirect immunofluorescence reaction and parasitological examination.

NUNES, D. C. O. S. et al.

Table 4. Diagnosis, treatment and case evolution of tegumentary and visceral leishmaniasis in Patrocínio (MG), 2000-2017.

\begin{tabular}{|c|c|c|c|c|c|c|}
\hline \multirow{2}{*}{\multicolumn{2}{|c|}{ Feature }} & & \multicolumn{2}{|c|}{ TL } & \multicolumn{2}{|c|}{ VL } \\
\hline & & & $\mathbf{N}$ & $\%$ & $\mathbf{N}$ & $\%$ \\
\hline \multirow{13}{*}{ 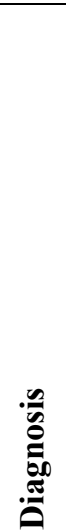 } & \multirow{3}{*}{ Parasitologic } & Positive & 1 & 6.67 & 0 & 0.00 \\
\hline & & Negative & 0 & 0.00 & 2 & 28.57 \\
\hline & & Not performed & 14 & 93.33 & 5 & 71.43 \\
\hline & \multirow{4}{*}{ Montenegro skin test } & Positive & 11 & 73.33 & & \\
\hline & & Negative & 1 & 6.67 & & \\
\hline & & Not performed & 3 & 20.00 & & \\
\hline & & Presence of parasite & 1 & 6.67 & & \\
\hline & \multirow[t]{3}{*}{ Histopathology } & Compatible & 6 & 40.00 & & \\
\hline & & Incompatible & 3 & 20.00 & & \\
\hline & & Not performed & 5 & 33.33 & & \\
\hline & \multirow[t]{3}{*}{ Indirect Imunofluorescence } & Positive & 0 & 0 & 1 & 14.29 \\
\hline & & Negative & 0 & 0 & 5 & 71.43 \\
\hline & & Not performed & 15 & 100 & 1 & 14.29 \\
\hline \multirow{4}{*}{\multicolumn{2}{|c|}{$\begin{array}{l}\text { Not confirmed } \\
\text { Confirmed }\end{array}$}} & & & & 6 & 85.71 \\
\hline & & Autochthonous & 5 & 33.33 & 1 & 14.29 \\
\hline & & Imported & 8 & 53.33 & 0 & 0.00 \\
\hline & & Undetermined & 2 & 13.33 & 0 & 0.00 \\
\hline \multirow{3}{*}{\multicolumn{2}{|c|}{ Confirmation criteria }} & Laboratory & 14 & 93.33 & 1 & 14.29 \\
\hline & & Clinic-epidemiologic & 1 & 6.67 & 0 & 0.00 \\
\hline & & Not informed & 0 & 0.00 & 6 & 85.71 \\
\hline \multirow{3}{*}{\multicolumn{2}{|c|}{ Treatment }} & Yes & 15 & 100.00 & 1 & 14.29 \\
\hline & & No & 0 & 0.00 & 6 & 85.71 \\
\hline & & Not informed & 0 & 0.00 & 0 & 0.00 \\
\hline \multirow{5}{*}{\multicolumn{2}{|c|}{ Drug used in treatment }} & Pentavalent antimony & 15 & 100.00 & 1 & 100.00 \\
\hline & & Anphotericin B & 0 & 0.00 & & \\
\hline & & Pentamidine & 0 & 0.00 & & \\
\hline & & Other & 0 & 0.00 & & \\
\hline & & Not used & 0 & 0.00 & & \\
\hline \multirow{6}{*}{\multicolumn{2}{|c|}{ Prescribed dose $\left(\mathrm{mg} / \mathrm{kg} / \mathrm{dia} \mathrm{Sb}^{+5}\right)$}} & $<10$ & 2 & 13.33 & & \\
\hline & & $\geq 10 e<15$ & 3 & 20.00 & 1 & 100.00 \\
\hline & & 15 & 0 & 0.00 & & \\
\hline & & $>15 e<20$ & 7 & 46.67 & & \\
\hline & & $\geq 20$ & 1 & 6.67 & & \\
\hline & & Not informed & 2 & 13.33 & & \\
\hline \multirow{5}{*}{\multicolumn{2}{|c|}{ Case evolution }} & Cure & 13 & 86.67 & 6 & 85.71 \\
\hline & & Abandonment & 0 & 0.00 & 0 & 0.00 \\
\hline & & Death from the disease & 0 & 0.00 & 0 & 0.00 \\
\hline & & Death from other causes & 0 & 0,00 & 1 & 14.29 \\
\hline & & Not informed & 2 & 0.00 & 0 & 0.00 \\
\hline \multicolumn{3}{|c|}{ Total } & 15 & 100.00 & 7 & 100.00 \\
\hline
\end{tabular}


All cases of TL and the only confirmed case of VL were treated, and the first-choice drug used in all cases was pentavalent antimonial, with doses varying mainly between 15 and $20 \mathrm{mg} / \mathrm{kg}$ /day of $\mathrm{Sb}^{+5}$ (Table 4). The only confirmed case of VL was initially treated with glucantime, but replaced with amphotericin B due to failure of the initial treatment. In another study in Minas Gerais (SILVA, 2017), cases of VL were initially treated with antimonial and replaced with amphotericin B (deoxycholate or liposomal) in the event of therapeutic failure. Araújo and Nunes (2017) observed that the most used treatment for TL in the cutaneous and mucosal forms was glucantime, alone or in combination with pentoxifylline, while treatment for VL was performed with amphotericin $\mathrm{B}$ or glucantime. In the present study, all victims were cured. Only one victim of VL died, but the death was unrelated to the disease.

All TL cases were considered to be new ones, i.e., none was a relapse. As for VL, the information was undocumented. Most of the notified cases $(53 \%)$ were classified as imported, but it is relevant to note that 5 new cases of TL and 1 case of VL were confirmed as autochthonous.

\section{CONCLUSIONS}

The most victims of leishmaniasis had the following profile: economically active males from the urban area, without no direct relationship between the disease and their professional activities.

Twenty-two cases of leishmaniasis were notified, 15 of which were TL and 7 were VL. The confirmed cases were treated and cured, which is a positive finding given treatment difficulties (drug availability, need for hospital admission, route of administration, side effects, etc.) which often result in abandoned treatment.

Although the number of cases was not high, 5 cases of TL were considered autochthonous and 1 case of VL was confirmed and considered autochthonous. Additionally, confirmed cases of infection in dogs occurred in 2011, 2016, and 2017. This should be seen as an alert for epidemiological surveillance and further attention to the disease, especially regarding the presence of canine infection and the investigation of phlebotomine fauna in Patrocínio.

\section{ACKNOWLEDGEMENTS}

The authors thank to the Health Department of Patrocínio, especially Gilberto Martins Júnior, for providing the information recorded in the epidemiological surveillance archives.

RESUMO: A leishmaniose é uma doença que pode afetar órgãos viscerais (leishmaniose visceral; LV) ou as mucosas e a pele, provocando lesões de diferentes formas e gravidades (leishmaniose tegumentar; LT). Como várias outras moléstias, a leishmaniose é uma doença negligenciada, já que a indústria farmacêutica parece mostrar pouco ou nenhum interesse em desenvolver novos medicamentos direcionados à enfermidade. $\mathrm{O}$ estudo teve como objetivo traçar o perfil epidemiológico da leishmaniose no município de Patrocínio, estado de Minas Gerais, ao longo de um período de tempo. Dados secundários de casos registrados no período de 2000 a 2017 foram analisados, conforme fornecido pelo Departamento de Saúde de Patrocínio. Como não foi encontrada literatura sobre a situação dessa doença em Patrocínio, é importante traçar o perfil epidemiológico da leishmaniose na região. Os achados apontaram que a doença afetou predominantemente o sexo masculino da população economicamente ativa, principalmente da área urbana, e que não tinha relação com a atividade profissional. Foram notificados 22 casos de leishmaniose (15 de LT e 7 de LV), todos tratados e curados. Cinco casos de LT e 1 de LV foram considerados autóctones, e houve casos confirmados de infecção canina nos anos de 2011, 2016 e 2017.

PALAVRAS-CHAVE: Alto Paranaíba. Autóctone. Leishmaniose humana. Triângulo Mineiro.

\section{REFERENCES}

ANVERSA, L.; TIBURCIO, M. G. S.; RICHINI-PEREIRA, V. B.; RAMIREZ, L. E. Human leishmaniasis in Brazil: a general review. Revista da Asssociação Médica Brasileira, v. 64, n. 3, p. 281-289, 2018. https://doi.org/10.1590/1806-9282.64.03.281 
ARAÚJO, T. T.; NUNES, D. C. O. A fourteen-year retrospective of clinic-epidemiological aspects of cutaneous and visceral leishmaniasis in Uberlândia, Minas Gerais, Brazil. Bioscience Journal, Uberlândia, v. 33, n. 4, p. 1054-1064, 2017. https://doi.org/10.14393/BJ-v33n4a2017-36986

ASFARAM, S.; TESHNIZI, S. H.; FAKHAR, M.; BANIMOSTAFAVI, E. S.; SOOSARAEI, M. Is urine a reliable clinical sample for the diagnosis of human visceral leishmaniasis? A systematic review and metaanalysis. Parasitology International, v. 67, p. 575-583, 2018. https://doi.org/10.1016/j.parint.2018.05.008

BORGES, G. L. F. N. Leishmaniose visceral canina no município de Uberlândia, Minas Gerais, outubro 2007 a fevereiro de 2008. 2008, 56p. Dissertação (mestrado). Universidade Federal de Uberlândia, Programa de Pós-Graduação em Ciências Veterinárias, Uberlândia, 2008.

BRASIL. Ministério da Saúde. Secretaria de Vigilância em Saúde. Departamento de Vigilância Epidemiológica. Manual de vigilância e controle da leishmaniose visceral / Ministério da Saúde, Secretaria de Vigilância em Saúde, Departamento de Vigilância Epidemiológica. - 1. ed., 5. reimpr. - Brasília: Ministério da Saúde, 2014. 120 p.: il.

BRASIL. Ministério da Saúde. Secretaria de Vigilância em Saúde. Departamento de Vigilância das Doenças Transmissíveis. Manual de vigilância, prevenção e controle de zoonoses: normas técnicas e operacionais. Ministério da Saúde, Secretaria de Vigilância em Saúde, Departamento de Vigilância das Doenças Transmissíveis. - Brasília: Ministério da Saúde, 2016. 121 p.

BRASIL. Ministério da Saúde. Secretaria de Vigilância em Saúde. Departamento de Vigilância das Doenças Transmissíveis. Manual de vigilância da leishmaniose tegumentar. Ministério da Saúde, Secretaria de Vigilância em Saúde, Departamento de Vigilância das Doenças Transmissíveis. - Brasília: Ministério da Saúde, 2017. 189 p.: il.

ELMAHALLAWY, E. K.; MARTINEZ, A. S.; RODRIGUEZ-GRANGER, J.; HOYOS-MALLECOT, Y.; AGIL, A.; MARI, J. M. N.; FERNANDEZ, J. G. Diagnosis of leishmaniasis. The Journal of Infection in Developing Countries, v. 13, n. 8, p. 961-972, 2014. https://doi.org/10.3855/jidc.4310

HANDLER, M. Z.; PATEL, P. A.; KAPILA, R.; AL-QUBATI, Y.; SCHWARTZ, R. A. Cutaneous and mucocutaneous leishmaniasis: differential diagnosis, diagnosis, histopathology and management. Journal of the American Academy of Dermatology, v. 7, n. 6, p. 911-926, 2015.

https://doi.org/10.1016/j.jaad.2014.09.014

HOCHMAN, B.; NAHAS, F. X.; FILHO, R. S. O.; FERREIRA, L. M. Desenhos de pesquisa. Acta Cirúrgica Brasileira, v. 20, suppl. 2, p. 1-9, 2005. https://doi.org/10.1590/S0102-86502005000800002

IBGE - Instituto Brasileiro de Geografia e Estatística. Divisão Territorial do Brasil e Limites Territoriais. Available in:

ftp://geoftp.ibge.gov.br/organizacao_do_territorio/estrutura_territorial/divisao_territorial/ (20/04/2019)

IBGE - Instituto Brasileiro de Geografia e Estatística. Estatística por cidade e estado. Available in: https://www.ibge.gov.br/cidades-e-estados/mg/patrocinio.html? (20/04/2019).

LEMOS, J. C.; LIMA, S. C. Leishmaniose tegumentar americana: flebotomíneos em área de transmissão no Município de Uberlândia, MG. Revista da Sociedade Brasileira de Medicina Tropical, v. 38, n. 1, p. 22-26, 2005. https://doi.org/10.1590/S0037-86822005000100005

MACHADO, M. I.; COSTA-CRUZ, J. M.; GONÇALVES, M.R.F.; FERREIRA, M. S.; NISHIOKA, S. A. American cutaneous leishmaniasis (ACL) in Triângulo Mineiro and Alto Paranaíba, Minas Gerais:

Parasitological diagnosis. Memórias do Instituto Oswaldo Cruz, v. 83, p. 44, Supl. 1, 1988. 
First epidemiological description...

NUNES, D. C. O. S. et al.

MACHADO, M. I.; NISHIOKA, S. A.; FERREIRA, M. S.; COSTA-CRUZ, J. M.; ROCHA, A.; SILVA, A. M.; SILVA, M.; GONCALVES-PIRES, M. R. F. Leishmaniose tegumentar americana no Triângulo Mineiro e Alto Paranaíba, Minas Gerais, Brasil: aspectos clinico-laboratoriais e epidemiológicos de uma microepidemia. Revista do Centro de Ciências Biomédicas da Universidade Federal de Uberlândia, v. 8, n. 1, p. 17-28, 1992.

MARTÍNEZ, D. Y.; VERDONCK, K.; KAYE, P. M.; ADAUI, V.; POLMAN, K.; LLANOS-CUENTAS, A.; DUJARDIN, J. C.; BOELAERT, M. Tegumentary leishmaniasis and coinfections other than HIV. PLOS Neglected Tropical Diseases, p. 1-20, 2018. https://doi.org/10.1371/journal.pntd.0006125

MAYWALD, P. G.; MACHADO, M. I.; CRUZ, J. M. C.; OLIVEIRA, M. G.; PIRES, M. R. F. G. Leishmaniose tegumentar canina: inquérito soroepidemiológico em áreas rural e urbana no município de Uberlândia, Minas Gerais. Brazilian Journal of Veterinary Research and Animal Science, v. 30, n. 1, p. 2529, 1993. https://doi.org/10.11606/issn.1678-4456.bjvras.1993.52013

MAYWALD, P. G.; MACHADO, M. I.; COSTA-CRUZ, J. M.; GONÇALVES-PIRES, M. R. F. Leishmaniose tegumentar, visceral e doença de Chagas caninas em municípios do Triângulo Mineiro e Alto Paranaíba, Minas Gerais, Brasil. Cadernos de Saúde Pública, v. 12, n. 3, p. 321-328, 1996. https://doi.org/10.1590/S0102311X1996000300005

MCGWIRE, B. S.; SATOSKAR, A. R. Leishmaniasis: clinical syndromes and treatment. International Journal of Medicine, v. 107, p. 7-14, 2014. https://doi.org/10.1093/qjmed/hct116

MENDONÇA, G. B. Positividade de Leishmania spp. em cães assintomáticos atendidos pelo programa de castração voluntária no Hospital Veterinário da Universidade Federal de Uberlândia. 2018, 48 f.

Monografia (Medicina Veterinária), Universidade Federal de Uberlândia, Uberlândia, 2018.

NAGLE, A. S.; KHARE, S..; KUMAR, A. B.; SUPEK, F.; BUCHYNSKYY.; MATHISON, C. J.; CHENNAMANENI, N. K.; PENDEM, N.; BUCKNER, F. S.; GELB, M. H.; MOLTENI, V. Recent developments in drug discovery for leishmaniasis and human African trypanosomiasis. Chemical Reviews, v. 26, n. 114, p. 11305-11347, 2014. https://doi.org/10.1021/cr500365f

NISHIOKA, S. A.; FERREIRA, M. S.; MACHADO, M. I.; SILVA, A. M.; ROCHA, A.; COSTA-CRUZ, J. M.; GONÇALVES, M. R. F. An outbreak of cutaneous leishmaniasis. Revista da Sociedade Brasileira de Medicina Tropical, v. 21, n. 4, p. 209, 1988. https://doi.org/10.1590/S0037-86821988000400010.

PACE, D. Leishmaniasis. Journal of infection, v. 69, p. 510-518, 2014.

https://doi.org/10.1016/j.jinf.2014.07.016

PAULA, M. B. C.; RODRIGUES, E. A. S.; SOUZA, A. A.; REIS, A. A.; PAULA, F. P.; PAJUABA NETO, A. A.; LIMONGI, J. E. Primeiro encontro de Lutzomyia longipalpis (Lutz \& Neiva, 1912) na área urbana de Uberlândia, MG, concomitante com o relato de primeiro caso autóctone de leishmaniose visceral humana. Revista da Sociedade Brasileira de Medicina Tropical, v. 41, n. 3, p. 304-305, 2008.

https://doi.org/10.1590/S0037-86822008000300016

PAUlA, M. B. C.; SOUZA, A. A.; REIS, A. A.; LIMONGI, J. E.; PAJUABA NETO, A. A.; RODRIGUES, E. A. S. Survey of sandfly fauna (Diptera: Psychodidae) in Uberlândia, Minas Gerais State, Brazil, 2003 - 2004.

Revista do Instituto de Medicina Tropical de São Paulo, v. 55, n. 2, p. 85-89, 2013.

https://doi.org/10.1590/S0036-46652013000200004

PREFEITURA DE PATROCÍNIO. Available in:

https://portal.patrocinio.mg.gov.br/pm/index.php/municipio/informacoes-sobre-o-municipio (20/04/2019). 
RODRIGUES, E. A. S.; ANDRADE-FILHO, J. D.; LIMONGI, J. E.; PAULA, M. B. C. Sandfly fauna (Diptera: Psychodidae) in Parque do Sabiá complex, Uberlândia, Minas Gerais, Brazil. Revista do Instituto de Medicina Tropical de São Paulo, v. 53, n. 5, p. 255-258, 2011. https://doi.org/10.1590/S003646652011000500003

SILVA, E. M.; MALVINO, S. S.B. Análise climática do município de Patrocínio (MG). Caminhos da Geografia, v.10, n.16, p.93-108, 2005.

SILVA, P. L. N.; ALVES, C. R.; CHAGAS, R. B.; MACEDO, L. P.; MAJUSTE, R.; SILVA, J. S. Características Epidemiológicas da Leishmaniose Tegumentar Americana no Norte de Minas Gerais. Revista Norte Mineira de Enfermagem, v. 2, n. 1, p. 43-50, 2014.

SILVA, T. A. M. Leishmaniose Visceral: análise espaço-temporal, avaliação do perfil clínicoepidemiológico e fatores associados ao óbito em Belo Horizonte e Minas Gerais. 2017, $151 \mathrm{f}$. Tese de doutorado. Universidade Federal de Minas Gerais, Instituto de Ciências Biológicas, Departamento de Parasitologia, Belo Horizonte, 2017.

SOUSA, R. G.; SANTOS, J. F.; RODRIGUES, H. G.; AVERSI-FERREIRA, T. A. Casos de leishmaniose visceral registrados no município de Montes Claros, estado de Minas Gerais. Acta Scientiarum. Health Sciences, v. 30, n. 2, p. 155-159, 2008. https://doi.org/10.4025/actascihealthsci.v30i2.671

SUNDAR, S.; CHAKRAVARTY, J. An update oh pharmacotherapy for leishmaniasis. Expert Opinion on Pharmacotherapy, v. 16, n. 2, p. 237-252, 2015. https://doi.org/10.1517/14656566.2015.973850

SUNYOTO, T.; BOELAERT, M.; MEHEUS, F. Understanding the economic impact of leishmaniasis on households in endemic countries: a systematic review. Expert Review of Anti-infective Therapy, v. 17, p. 5769, 2019. https://doi.org/10.1080/14787210.2019.1555471

VIANA, A. G.; SOUZA, F. V.; PAULA, A. M. B.; SILVEIRA, M. F.; BOTELHO, A. C. C. Aspectos clínicoepidemiológicos da leishmaniose tegumentar americana em Montes Claros, Minas Gerais. Revista Médica de Minas Gerais, v. 22, n. 1, p. 48-52, 2012.

WHO. World Health Organization. Available in: https://www.who.int/csr/resources/publications/CSR_ISR_2000_1leish/en/ (16/01/2020). 